\title{
QUALITY OF LIFE OF SUBJECTS WITH AND WITHOUT NOSE BREATHING DIFFICULTIES
}

\author{
QUALIDADE DE VIDA DE SUJEITOS COM E SEM DIFICULDADES DE \\ USO DE VIA NASAL
}

\begin{abstract}
Carla Patrícia Hernandez Alves Ribeiro CÉSAR ${ }^{1}$; Kelly da SILVA²; Luiz Renato PARANHOS ${ }^{3}$; Sílvia Elaine Zuim de Moraes BALDRIGHI ${ }^{4}$

1. Professor, Department of Speech Therapy, Federal University of Sergipe, Lagarto, SE, Brazil. carlacesar@ globo.com; 2. Professor, Department of Speech Therapy, Federal University of Sergipe, Lagarto, SE, Brazil; 3. Professor, Department of Dentistry, Federal University of Sergipe, Lagarto, SE, Brazil; 4. Professor, Department of Speech Therapy, Federal University of Sergipe, Aracaju, SE, Brazil.
\end{abstract}

\begin{abstract}
The aim of this study was to compare the perception of the parents about the quality of life of children and adolescents with and without difficulties of nasal route use. The Protocols of Quality of Life of Oral Breathing Children and MBGR (subitems Clinical History and Breathing) were applied to 64 families with and without complaints about mouth breathing. The sample consisted of subjects aged between five and sixteen years old and was divided into two groups: Control Group (CG - 32 subjects, average age $9.78 \pm 2.71$ ), with the possibility of nasal route use with time equal or less than two minutes and Experimental Group (GE - 32 subjects, average age: 9.59 years), with the possibility of nasal use for less than two minutes. The possibility of the nasal use was evaluated with the use of a timer, requiring the maintenance of a small amount of water in the mouth for, at least, two minutes. If the subject remained unquiet or swallowed before the stipulated time, it was carried with retest for two more attempts, to ensure the obtained results. ANOVA test was applied, considering $\mathrm{p}$ value of $5 \%$ was. There were no significant statistically differences between the studied groups $(\mathrm{p}>0,05)$. It can be concluded that despite the complaints related to the breathing mode of children and adolescents with familiar complaints about mouth breathing, these do not seem to have interfered directly in the quality of life, according to the Protocol used.
\end{abstract}

KEYWORDS: Quality of Life. Sickness Impact Profile. Mouth Breathing.

\section{INTRODUCTION}

The use of protocols with scores in clinical practice in orofacial motricity has arisen from the need for a standardization of orofacial myofunctional evaluation, as well as to obtain comparison parameters of pre- and postintervention, including treatments and researches, promoting the measurement of the perception of the evaluator about structural and functional aspects of the orofacial and cervical regions (GENARO; FELÍCIO, 2014).

The protocols used are the Protocolo de Avaliação Miofuncional Orofacial com Escores (Myofunctional Orofacial Assessment Protocol with Scores) [AMIOFE] developed by Felício and Ferreira, in 2008 (FELÍCIO; FERREIRA, 2008) and the MBGR, in 2009 (GENARO et al, 2009), being the breathing mode evaluated by both, although with different procedures and scores (GENARO; FELÍCIO, 2014).

The altered breathing mode, whether oral or mixed (oral and nasal simultaneously), interests to various specialties in Health (especially in Otolaryngology, Speech, Language and Hearing Sciences and Dentistry), due to the nasal breathing, which favors the proper blood oxygenation and the quality of life (DEGAN; GUIMAR ÃES, 2014).

Through bibliographic review, it can be seen that there is a consensus in literature in stating that the impact of respiratory diseases such as asthma and allergic rhinitis and the alteration in the breathing mode (mouth) affect directly the quality of life of the affected subject, both by breathing alteration and by losses in other domains of life, such as behavior and functional and physical aspects (CAMPANHA; FREIRE; FONTES, 2008), although few Quality of Life Protocols (QoL) have been developed to measure whether exist or not such impairment to mouth breathers. There are QoL protocols to evaluate the impact on obstructive sleep apnea, as well as the Obstructive Sleep Apnea, the OSA-18 (SILVA; MILK, 2006) and Pittsburgh (Bertolazi, 2008), with asthma (PAQLQ-A) of La Scala; Naspitz; Solé (2005) and the Questionnaire of Evaluation of the Quality of life in children with the adenoids and palatines tonsils enlarged, developed by Serres et al. (2002), adapted and validated by $\mathrm{Di}$ Francesco et al. (2004).

In order to evaluate the QoL of mouth breathing children, Ribeiro (2006) has developed and applied a structured questionnaire in 75 children 
(between six and twelve years old) and their guardians in a Reference Center of the Universidade Federal de Minas Gerais, noting that respondents showed ease in filling it and that the obstructions of the upper respiratory tract, in the perspective of the children, did not compromise their QoL.

César et al. (2010) applied the referred protocol to 74 families, whose children aged between three and 16 years old, being the sample divided from the degree of impairment of the breathing mode (degrees 0 to III), being the degree III considered the one with greater impairment. They found changes in QoL only in subjects with degree III, with impact in general issues, as well as in nasal aspects, sleep, feeding and atopy. But language and emotional aspects did not seem to interfere in the quality of life of the studied group.

Thus, further studies with the use of quality of life protocols in mouth breathers need to be made. Therefore, the aim of this study was to compare the perception of parents about the quality of life of children and adolescents with and without difficulties of nasal route use.

\section{MATERIAL AND METHODS}

It is a cross-sectional study, not random, with the sample composition by convenience and performed in a single research center, with the prior approval of collegiate agencies of the Institution of origin. The project was approved by the Ethics Committee in Research with the protocol No. 324501-10, complying with the Resolution of the National Health Council No. 466/12, of December 12, 2012.

The scheduled relatives were invited to participate in the proposal, in day and time predetermined, for the orthodontic screening process of the Universidade Metodista de São Paulo.

The data collection was performed by applying two protocols. The first one, which would serve to facilitate the selection of subjects that would compose the sample (MBGR of GENARO et al., 2009) and the second one, which would give evidences if the study variable would or would not bring adverse consequences for the quality of life of the studied groups (RIBEIRO, 2006), as described below.

\section{Description of data collection instruments}

The Clinical History was composed by closed and opened questions, containing the data of identification, complaint, family history, complications, motor development, health and respiratory problems, eating, sleeping, oral habits and others that constitute the MBGR Protocol (GENARO et al., 2009).

For the evaluation of the breathing function, it was used the Breathing subsection of the MBGR Protocol (GENARO et al., 2009), being observed:

1) Mode - after cleaning the nostrils, it was preceded a classification depending on the maintenance of sealed lips or tongue in palatine papilla during the inspiration, and being possible to be marked as nasal (score zero), mixed (score one) or oral (score two).

2) Nasal Expiratory Airflow - with and without cleaning the nostrils, checking the symmetry of the referred flow between the nostrils, with the aid of a metallic plate under the nostrils, marking the haze obtained by the nasal exhalation. It is noteworthy that the environment was not refrigerated and the obtained result was transposed to tally sheet, in the sheet itself, with the use of a marker for overhead projector of the brand Pilot. It was recorded if the flow was symmetric (score zero) or reduced to the right (score one) or to the left (score one).

3) Possibility of nasal route use - evaluated with manual stopwatch use (Mark1 TM), requesting the maintenance of small amount of water in the mouth, without swallowing it for, at least, two minutes. If the subject remained restless or swallowed it before the stipulated time, it was carried with retest for two more trials, to ensure the obtained results. The score zero was attributed to those who managed to stay with water in the mouth for two minutes or more, the score one for the ones who managed to stay between one and two minutes and the score two for those who stayed for less than a minute with water in the mouth.

At the end, were obtained scores between zero and eight, with zero being considered the best result and eight, the worst, as recommended by the creators of the Protocol.

The second part consisted of 32 questions related to the perception of the relative about the impact of mouth breathing in quality of life Protocol of Quality of Life for Mouth Breathers, adapted from Ribeiro (2006).

To elaborate the QoL protocol, Ribeiro observed clinical consultations, data of medical records and interviews (with experienced professionals and relatives of the mouth breathers with clinical diagnosis of respiratory changes caused by allergic rhinitis, asthma and atopy), and the instrument was rated according to its reliability, responsiveness (sensibility) and interpretability.

The protocol adapted from Ribeiro (2006) was composed of six specific domains and two general questions. All questions were closed and 
composed of three multiple choices: no, sometimes and yes. The scores, for each question, ranged from zero to two points, and when the marked alternative was "sometimes", it would be assigned one point.

The domain related to the nasal aspect comprised eight questions, being possible to totalize sixteen points. The questions were: "Does your child usually feel uncomfortable because of his nose?", "Does your child usually snore at night?", "Does your child usually present itchy nose?", "Does the nose of your child tend to get runny?", "Does your child present frequent sneezing? ", "Does your child usually get stuffy nose?", "Does your child usually get upset because of his nose?" and "Does your child usually feel 'itchy' in his mouth or in his throat?". In this item, for each negative answer, there would not be a score and, for each positive answer, two points.

There were seven questions that evaluated the sleep, making it possible to sum up to 14 points. The questions were: "Is his sleep usually quiet?", "Does your child usually complain about being sleepy during the day?", "Does your child usually sleep with his mouth open?", "Does your child prefer a higher pillow?", "Does your child usually wake up in the night?", "Does your child usually wake up with the mouth dry?" and "Does your child usually drool on the pillow?". For each negative answer, two points were assigned and for affirmative answers, none.

Feeding and language were evaluated by three questions each, totaling a maximum of six points for each domain. The questions related to feeding were: "Does your child usually chew his food well?", "Does your child usually drink liquids during meals?", and "Does your child usually stop eating to breathe?". The questions related to language were: "Is it generally understood when your child speaks?", "Does your child usually spit while talking?" and "Does your child usually have difficult to read or to write?". In the feeding domain, for each affirmative answer, it was assigned two points and, for the negative ones, none. The opposite occurred for language.

The emotional domain was checked by four questions, with a maximum score of eight points, namely: "Does your child usually get embarrassed?", "Does your child usually get impatient?", "Does your child usually get angry?" and "Does your child usually get nervous?", and, if the answer was negative, no score was assigned and, if positive, two.

The atopy included five questions (total $=$ ten points): "Does your child usually feel itchy eyes?", "Does your child usually cough while playing or running?", "Does your child usually cough at night?", "Does your child usually experience shortness of breath?" and "Does your child often feel itchy skin?". When signaled the negative answer, no score was assigned and two points were assigned when the answer was affirmative.

The general questions concerned the nuisance of the parents about the respiratory condition and their perception of the impact of breathing on the quality of life of their children, totaling four points (for affirmative answers, two points were conferred and for the negatives, none).

In general, the instrument allowed a score between zero and 64 points, and the lower the score, the better could be considered the quality of life of the subject.

\section{Eligibility Criteria for Sample Composition}

As a criterion of inclusion of the subjects in the research, it was applied the Clinical History of the MBGR Protocol (GENARO et al., 2009) in which, the relative/s of the subjects in the experimental group (EG) should present complaints about the changed breathing mode for a minimum period of six months and the informant/s should reside with the child or adolescent, while the control group (CG), should not have complaints about breathing. Other inclusion criterion adopted for both groups was about schooling, in which the participants should have, at least, the elementary school to the fourth year, since they should respond to the QoL Protocol through reading the instrument.

Next, the speech therapy clinic evaluation of breathing about its mode was performed, nasal airflow and the possibility of nasal route use. Therefore, it was used the subsection of Breathing, of the Myofunctional Orofacial Evaluation Protocol (MBGR Protocol, from GENARO et al., 2009), by a single and previously trained evaluator.

The exclusion criteria adopted were: positive history of surgeries (facial or nasopharyngeal), neurological or genetic alterations, craniofacial malformations, or even, presence of fissures (lips, palate or uvula). The parents were asked about the presence of disabilities (mental or auditory) of their children. If the answer was affirmative, they were also excluded from the sample.

\section{Selection and Characterization of the sample}

For the composition of the study sample, it was drawn a sample calculation from the total of patients screened in service (102 patients). Therefore, the confidence interval of $95 \%$ and a 
margin of error of $10 \%$ were used, being obtained the amount of 64 subjects.

After applying the eligibility criteria, the subjects of the sample (64), that aged between five and sixteen years old (39 males - 60.94\% and 25 females - $39.06 \%$ ), were divided into two groups, and matched by sex and age.

The control group (CG) consisted of 32 children and adolescents with an average age of 9.78 years old $( \pm 2.71)$, twenty were male $(62.5 \%)$ and twelve, female $(37.5 \%)$, with the possibility of nasal route use with time equal or higher than two minutes and/or score zero in breathing mode, whose relatives did not present complaints related to breathing mode and had sealed lips during the interview and the application of the MBGR.

The experimental group (EG) was also composed by 32 subjects, with an average age of 9.59 years old $( \pm 3.1)$, nineteen were male $(59.38 \%)$ and thirteen were female $(40.62 \%)$, with the possibility of nasal use for less than two minutes, with score one or two in breathing mode, whose relatives presented complaints about mouth breathing and that remained during the interview and screening process with the lips opened or partially opened (observed even after the nasal cleansing requested).

\section{Analysis of the Results}

The results were transcribed into the Excel spreadsheet software (Microsoft Office ${ }^{\mathrm{TM}}$ ) for a descriptive data analysis. For statistical analysis, the ANOVA test was used to check the existence among the findings of the questionnaire of control and experimental groups. It used the program Statistical Package for the Social Sciences - IBM SPSS $^{\mathrm{TM}}$ version 16.0 for Windows (SPSS Inc., from 1989-2006, Chicago, Illinois, USA), settling the significance level in $5 \%$.

\section{RESULTS}

No significant statistically differences were found between the Control and the Experimental Groups for any of the domains evaluated by the Quality of life Protocol used ( $\mathrm{p}>0.05$ for all domains, Figure 1).

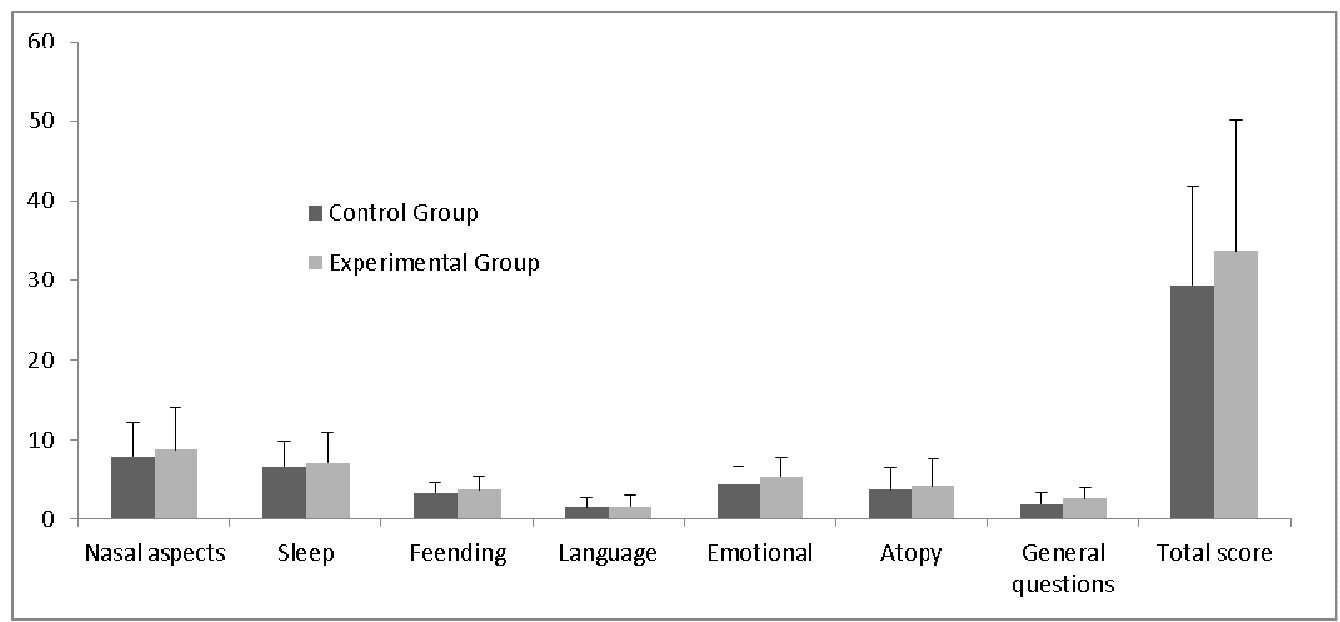

Figure 1. Comparison of the average scores achieved in implementing the Quality of Life Protocol between the control and experimental groups, by the ANOVA test.

\section{DISCUSSION}

Several instruments created to evaluate the quality of life of children have been validated for Brazilian Portuguese, as the Autoquestionnaire Qualité de Vie Enfant Imagé (AUQEI), the Child Health Questionnaire - Parent Form 50 (CHQPF50), the Pediatric Quality of Life Inventory (Peds $Q{ }^{\mathrm{TM}}$ ) version 4.0 and the Kidscreen-52, but some protocols do not include all childhood ages or do not have domains considered relevant in the children's context today, requiring adjustments to the existing instruments or validation of others
(SOUZA et al., 2014). Regarding the quality of life protocols that aimed at analyzing the impact of respiratory problems, exist the OSA-18 and Pittsburg, focused on the OSA (SILVA; LEITE, 2006; BERTOLAZI, 2008), the PAQLQ-A, for subjects with asthma (LA SCALA; NASPITZ; SOLÉ, 2005) and the Protocol advocated by Ribeiro (2006), which is the only one that evaluates the mouth breather, without distinction of condition, but still unused by the scientific literature.

Thus, it interests to the researchers of the area, to check the applicability of available protocols, as well as to stablish commonly used 
statements in the area, like the one that affirms that mouth breathing jeopardizes the quality of life of affected individuals.

Thus, it was opted the application of the reduced form of the Quality of Life of Mouth Breathers Protocol (RIBEIRO, 2006), through the response of the family members who live daily with the child or the adolescent screened. Despite the author suggestion of the application to mouth breathing children, we chose not to perform such application because of the need to include colorful plates that could illustrate the issue to be addressed, so that, the child could manipulate them and proceed with the answer, using arrows or pawns, like the Inventaire Systémique de Qualité de Vie pour Enfants (ISQV-C), French instrument already validated for the Portuguese of Portugal (FONSECA et al., 2014), but not for the Brazilian one.

Regarding the applicability of the instrument, similar to the one reported by its creator (RIBEIRO, 2006), the protocol was well accepted and easily understood by respondents, not requiring the applicator intervention under any circumstances.

In this study, the groups were divided regarding the possibility of nasal use and presence or absence of complaints about mouth breathing by family members. This option has been adopted due to the lack of an otolaryngologist in the Orthodontics section of the research center, however, in the conducted interview, all relatives of the EG already reported having gone through otorhinolaryngologic evaluation, with a history of allergic rhinitis, colds and constant tonsillitis, sinusitis and, occurring less, bronchitis and asthma. It should be noted, however, that allergic rhinitis was also cited by the family members of the participants in the CG, totaling the presence in $65 \%$ of the sample ( $n=41,64.06 \%)$ - which may be a weakness of the study.

However, allergic rhinitis and bronchial asthma are chronic diseases that affect mainly children and adolescents, and can cause hospitalization. In industrialized countries, the number of cases grows every year, generating a constant need for research. The age group between six and seven years old seems to be the most susceptible to environmental conditions that favor the emergence of these diseases (such as ambient humidity) together and, thereby, compromising significantly the quality of life of children (PENDLOSKI, 2014).

In this study, despite the high occurrence of allergic rhinitis complaints, the average age of the groups was higher (CG: 9.78 and EG: 9.59), which can justify the non-impairment of quality of life among the subjects investigated.

Another hypothesis concerns the data collection protocol (MBGR), which may indicate that clinical evaluation may not be sufficient for the comparison of groups; that the etiological factors cited by the responsible family members did not affect the quality of life of the EG; or even that the mentioned medical conditions were not chronic enough to affect the QoL, deserving the inclusion of other variables in the process of selection between groups, such as otorhinolaryngologic evaluation, the simultaneous application of other quality of life protocols and the composition of larger groups.

However, despite the abovementioned weaknesses, it can be seen, at least in the investigated groups, that the quality of life was not affected by mouth breathing, and one should take caution with statements indicating such association.

\section{CONCLUSION}

Despite complaints related to the respiratory mode in children and adolescents with difficulties in using the nasal route, resulting in the need for mouth breathing, these do not seem to have interfered directly in the quality of life.

RESUMO: O objetivo deste estudo foi comparar a percepção de pais acerca da qualidade de vida de crianças e adolescentes com e sem dificuldades de uso de via nasal. Os protocolos de Qualidade de Vida de Crianças Respiradoras Orais e MBGR (subitens História Clínica e Respiração) foram aplicados a 64 familiares com e sem queixa de respiração oral. A amostra foi composta por sujeitos com idades entre cinco e dezesseis anos e foi dividida em dois grupos: Grupo Controle (GC - 32 sujeitos, média de idade: 9,78 $\pm 2,71$ ), com possibilidade de uso de via nasal com tempo igual ou superior a dois minutos e Grupo Experimental (GE - 32 sujeitos, média de idade: 9,59 anos), com possibilidade de uso nasal inferior a dois minutos. A possibilidade de uso nasal foi avaliada com uso de cronômetro, solicitando-se a manutenção de pequena quantidade de água na boca por, no mínimo, dois minutos. Caso o sujeito permanecesse inquieto ou deglutisse antes do tempo estipulado, foi procedido com reteste por mais duas tentativas, a fim de assegurar os resultados obtidos. Foi aplicado o teste ANOVA, considerando-se p valor de 5\%. Não foram encontradas diferenças estatisticamente significantes entre os grupos de estudo $(\mathrm{p}>0,05)$. Foi possível concluir que apesar das queixas relacionadas ao modo respiratório de crianças e adolescentes com queixas familiares de respiração oral, estas parecem não ter interferido diretamente na qualidade de vida, de acordo com o Protocolo utilizado. 
PALAVRAS-CHAVE: Qualidade de Vida. Perfil de Impacto da Doença. Respiração Bucal.

\section{REFERENCES}

BERTOLAZI, A. N. Tradução, adaptação cultural e validação de dois instrumentos de avaliação do sono: escala de sonolência de Epworth e índice de qualidade do sono de Pittsburgh. 2008. Dissertação (Mestrado em Ciências Médicas) - Programa de Pós-Graduação em Medicina, Ciências Médicas, Universidade Federal do Rio Grande do Sul, Porto Alegre, Rio Grande do Sul.

CAMPANHA, S. M. A.; FREIRE, L. M. S.; FONTES, M. J. F. O impacto da asma, da rinite alérgica e da respiração oral na qualidade de vida de crianças e adolescentes. Rev. CEFAC, São Paulo, v. 10, n. 4, p. 513519, 2008. http://dx.doi.org/10.1590/S1516-18462008000400011

CÉSAR, C. P. H. A. R.; PITUBA, A.; GOULART, F.; SOARES, R. R.; TESSITORE, A.; NEMR, K. N. A qualidade de vida de crianças e adolescentes com queixa de respiração oral sob a ótica de seus pais. 2010. 20f. Monografia (Especialização em Motricidade Orofacial) - Lato Sensu em Motricidade Orofacial, CEFAC, São Paulo, 2010.

DEGAN, V. V.; GUIMARÃES, K. C. C. Respiração - intervenção fonoaudiológica. In: MARCHESAN, I. Q.; SILVA, H. J.; TOMÉ, M. C. (Org). Tratado das especialidades em Fonoaudiologia. Rio de Janeiro: Guanabara-Koogan, 2014. p. 326-336.

DI FRANCESCO, R. C.; FELIPE, S. G.; KOMATSU, C. L. Melhora da qualidade de vida em crianças após adenoamigdalectomia. Rev Bras Otorrinolaringol., Rio de Janeiro, v. 70, n. 6, p. 748-751, 2004. http://dx.doi.org/10.1590/S0034-72992004000600006

FELÍCIO, C. M.; FERREIRA, C. L. P. Protocol of orofacial myofunctional evaluation with scores. Int. J. Pediatr. Otorhinolaryngol., Amsterdam, v. 72, n. 3, p. 367-375, 2008.

http://dx.doi.org/10.1016/j.ijporl.2007.11.012

GENARO, K. F.; BERRETIN-FELIX, G.; REHDER, M. I. B. C.; MARCHESAN, I. Q. Avaliação miofuncional orofacial: protocolo MBGR. Rev. CEFAC, São Paulo, v. 11, n. 2, p. 237-255, 2009. http://dx.doi.org/10.1590/S1516-18462009000200009

GENARO, K. F.; FELÍCIO, C. M. Protocolos clínicos de avaliação miofuncional orofacial. In: MARCHESAN, I. Q.; SILVA, H. J.; TOMÉ, M. C (Org). Tratado das especialidades em Fonoaudiologia. Rio de Janeiro: Guanabara-Koogan, 2014. p. 271-282.

LA SCALA, C. S. K.; NASPITZ, C. K.; SOLÉ, D. Adaptação e validação do Pediatric Asthma Quality of Life Questionnaire (PAQLQ-A) em crianças e adolescentes brasileiros com asma. J Pediatr., Rio de Janeiro, v. 81, n. 1, p. 54-60, 2005. http://dx.doi.org/10.1590/S0021-75572005000100011

PENDLOSKI, C. J. S. Prevalência e associações de risco asma e rinite em escolares de Guarulhos, São Paulo. 2014. 99f. Dissertação (Mestrado em Gestão Ambiental e Sustentabilidade) - Programa de PósGraduação em Administração, Universidade Nove de Julho, São Paulo, 2014.

RIBEIRO, M. L. Qualidade de vida no respirador oral: avaliação sistemática em crianças de 6 a 12 anos, atendidas em um centro de referência da UFMG. 2006. Dissertação (Mestrado em Saúde da Criança e do Adolescente) - Programa de Pós-Graduação em Ciências da Saúde, Universidade Federal de Minas Gerais, Belo Horizonte, Minas Gerais, 2006. 
SERRES, L. M.; DERKAY, C.; SIE, K.; BIAVATI, M.; JONES, J.; TUNKEL, D. et al. Impact of adenotonsillectomy on quality of life in children with sleep disorders. Arch Otolaryngol Head Neck Surg., Chicago, v. 128, n. 5, p. 489-496, 2002. http://dx.doi.org/10.1001/archotol.128.5.489

SILVA, V. C.; LEITE, A. J. M. Qualidade de vida em crianças com distúrbios obstrutivos do sono: avaliação pelo OSA-18. Rev. Bras. Otorrinolaringol., Rio de Janeiro, v. 72, n. 6, p. 747-756, 2006.

http://dx.doi.org/10.1590/S0034-72992006000600005

SOUZA, J. G. S.; PAMPONET, M. A.; SOUZA, T. C. S.; PEREIRA, A. R.; SOUZA, A. G. S.; MARTINS, A. M. E. B. L. Instrumentos utilizados na avaliação da qualidade de vida de crianças brasileiras. Rev Paul

Pediatr., São Paulo, v. 32, n. 2, p. 272-278, 2014. http://dx.doi.org/10.1590/0103-0582201432214313 